\title{
RICE BRAN PELLETS PRODUCTION BY USING AN EXPELLER MACHINE
}

\author{
Shoughy *, M. I. ; A. A. EL- Keway ** and Y. T. Hendawy**
}

\section{ABSTRACT}

Development and testing an expeller machine for oil extraction as a dual purpose for forming rice bran pellets to maximize the oil extraction rate during solvent extraction was carried out. Four screw revolving speed $(0.262,0.524,0.786$ and $1.05 \mathrm{~m} / \mathrm{s})$, three die hole diameter $(6,8$ and $10 \mathrm{~mm})$ as well as three levels of moisture content (11.1, 14.2 and 16.1\%, w.b.) of two rice bran components (white and dark bran) during extrusion process were used to investigate their effect on the machine performance and the resulting extrudate properties. The results revealed that, the extruder productivity of white bran at the same die hole diameter $(10 \mathrm{~mm})$ was increased by 30.3 , 35.4 and $25.8 \%$, specific energy requirement by 64.1, 56.7 and $70.4 \%$, durability by 31.7, 23.5 and 18.9\%, hardness by 60.1, 84.4 and $74.5 \%$ when screw speed increased from 0.262 to $1.05 \mathrm{~m} / \mathrm{s}$ with bran moisture content 11.1, 14.2 and $16.1 \%$, respectively. While, at the same screw speed $(0.786 \mathrm{~m} / \mathrm{s})$ and die hole diameter $(6 \mathrm{~mm})$, the productivity was decreased by $10.2 \%$ and hardness by $24.3 \%$, while energy requirement increased by $24.9 \%$ and durability by $10.5 \%$ with increasing moisture content. The same trend was noticed with various operating parameters of dark bran, but the productivity, pellets durability and hardness was higher value by about 12\%, 12.3 and 65.2\% than the values of white bran, while the energy requirement was lower value by $8 \%$. The regression equations were found and can be used to predict the change of extruder performance and quality of bran pellets under different operating conditions.

\section{INTRODUCTION}

\begin{abstract}
A $\mathrm{s}$ interest in value-added processing research grows, attempts are being made to increase the value of agricultural crop by-
products, including rice bran, by increasing their pharmaceutical or nutraceutical potential.
\end{abstract}

* Senior Researcher at the Agric. Eng. Res. Ins. (AEnRI), Dokki, Giza, Egypt. ** Researchers at the Agric. Eng. Res. Ins. (AEnRI), Dokki, Giza, Egypt. 
Rice bran is the most valuable by-product of the rice processing industry. It forms about $10 \%$ of the total grain and is highly nutritious, being rich in lipids, protein, minerals and vitamins. It is a major source of oil, with the oil content varying from $12-25 \%$ depending on the quality of bran and the degree of polishing. It contains $65 \%$ of nutrients found in rice kernel, Motthew (2009). He also reported that, if rice bran is stabilized without high heat or chemicals, it contains over 120 antioxidants cofactors and catalysts that can protect human cells from being damaged by free radicals. It contains various antioxidants that impart beneficial effects on human health. A major rice bran fraction contains highly unsaponifiable components (4.3\%). This fraction contains tocotrienols (a form of vitamin E), gamma-oryzanol, and beta-sitosterol; all these constituents may contribute to the lowering of the plasma levels of the various parameters of the lipid profile. Rice bran also contains a high level of dietary fibers (beta-glucan, pectin, and gum). In addition, it also contains 4-hydroxy-3-methoxycinnamic acid (ferulic acid), which is also a component of the structure of non-lignified cell walls.

The production of rice bran during milling process in Egypt may be approach 638,000 tons annually, Matouk et al.( 2009). Orthoefer (2005) reported that, the problems with rice bran are associated with its finely granulated nature and its tendency towards rapid conversion of the rice oil into free fatty acid after milling and, to a minor extent, the action of bacteria and molds in the presence of air and moisture. Fines cause problems in the clarification of miscella, the condensation of the finesladened vapor from the desolventizers and channeling within the baskets; they have become so troublesome as to force some operators to run their extractors far below capacity. Although proper sterilization of rice bran resulted in deactivation of the enzyme, the problems linked to the fines were not eliminated and continued to present plant processing difficulties. Size reduction of these residues, by compacting in pellets solves a great deal of these problems and mitigates the costs associated with their transportation, handling and storage. The densification of rice bran has been affected by several parameters which can be classified into parameters related to the raw materials such as rice variety, components, particle size and moisture content and pressing parameters such as 
capacity, pressure levels, press duration, dimensions and shape of pellets, and pressing temperature, ASAE Standard (2004). Kaliyan and Morey (2007) indicated that temperatures of around $85^{\circ} \mathrm{C}$ can occur in conventional ring-die pelleting machines due to frictional heating. Tumuluru et al. (2010) found that a larger die diameters of $7.2 \mathrm{~mm}$ produced less-durable DDGS pellets compared to a smaller die diameter of $6.4 \mathrm{~mm}$, for both with and without the addition of steam. Also, increasing the moisture content of ingredient blends from 15 to $25 \%$ (w.b.) resulted in a $28.2 \%$ increase in durability. Furthermore, increasing the screw speed and moisture content of the blends, resulted in an increase of 29.9 and $16.6 \%$ in extruder throughput, respectively. While, Chevanan et al.(2010) revealed that the torque and specific mechanical energy decreased as screw speed increased. Also, increasing the moisture content from 15 to $25 \%$ resulted in a $68.9 \%$ increase overall in the torque required. Thus, the specific mechanical energy was found to be lowest for the $15 \%$ moisture content and highest at $20 \%$ moisture content.

On the other hand, Abhay Sah et al. (1983) indicated that the time to reach $1 \%$ residual oil is an exponential function of the surface area/gram of pellets. The greater the length and diameter of the pellet, the lesser the surface area /gram; hence, the time to reach $1 \%$ residual oil increases considerably. The most important aspect is that for a given diameter, as the length of the pellet increases extraction time also increases. The shape of the pellets should be such that the surface area/gram is maximum. Takeshita(1984) reported that rice bran consists of fine particles, therefore, it is necessary to treat it in a pretreatment process before solvent extractions. The pretreatment consists of either of the following methods: 1) pelleting by hydration and pressing, 2) shaping flake by hydration at room temperature, and 3) hydration and agglomeration by expandlex method. Also, Kim et al. (1987) compared solvent extraction characteristics of rice bran pretreated by hot air drying, steam cooling and extrusion. As the results, palletized or extruded rice bran showed largest extraction rate to other pretreated bran. Orthoefer (2005) reported that the fines agglomeration, which is due to the starch gelatinization and protein denaturation contained in the bran, helps to increase the percolation rate of the treated material during solvent 
extraction. Also, the oil extraction rate of extruded rice bran pellets $(6-8$ $\mathrm{mm}$, in diameter) was rapid with $96 \%$ of the oil being removed in 5 minutes and only $0.7 \%$ residual oil remaining after 1 hour of extraction. Yasuhiko and Iwata (1988) reported that the stabilization process was not utilized in Japan, because rapid collection of rice bran from mill had been achieved, and the capacity of oil mill was excess to ingredient bran supply. While, in the ordinary case like in Egypt, the stabilization by extrusion or pelleting of rice bran is very useful, because the location of rice mill and rice bran oil factory one are dotted and the traffic condition is not suitable to rapid collection of bran. Measures need to be taken to remove obstacles to produce the maximum quantity of bran and to increase production of edible rice oil in the coming years. The review of literature showed a great shortage on the study of pelleting of rice bran. Efforts are been made to improve the performance of pellet extrusion through modifications in press design and by optimization. To increase production of oil from rice bran by solvent extraction in developing countries, there is a need to develop more efficient mechanical screw pelletizer. The main objectives of the present study were to:

1. Development and testing an expeller machine for oil extraction as a dual purpose for forming rice bran pellets to maximize the oil extraction rate during solvent extraction.

2. Study the effect of some operating parameters such as screw speeds, die hole diameter of extruder and moisture content of two rice bran components on machine productivity, power consumption, specific energy requirement and pellets quality (pellets durability index and hardness).

\section{MATERIALS AND METHODS}

\section{MATERIALS}

Fresh rice bran is using immediately after milling process. In this study, rice (Oryza sativa L.) bran samples, Sakha 101 rice variety, were obtained from a medium and large scale milling factory. The chemical composition of two rice bran components was analyzed. Sokhansanj et al. (2005) identified that the optimum moisture content for pelleting cellulosic material ranges from 8 to $12 \% \mathrm{w} . \mathrm{b}$, and the optimum moisture 
content for starch and protein material (most animal feeds) can reach $16 \%$ w.b. The purpose of selecting 14.2 and $16.1 \%$ w.b. as the two moisture contents for this set of experiments was to be able to significantly observe the effect of moisture on the quality of the pellets. To obtain the moisture content of 14.2 and $16.1 \%$, the appropriate amount of distilled water was added to the samples, mixed and tempering for accurate moisture content verification. The sample is storing in a freezing room in a sealed bags at a temperature of $-5^{\circ} \mathrm{C}$ until used.

\section{Rice Bran Components:}

Rice bran quality from rice milling processing includes quantity, type of structure and chemical composition of rice bran. These things depend on rice varieties, including the polish rice processing of brown rice, white polish and polishing for more white and shiny milled rice, Tangprawat (2006). The two rice bran components used in this study was classified as follows:

1. Bran (dark tan color): The bran from polishing of brown rice that has dark tan color. The bran consists of the pericarp, seed coat, nucleus, aleurone layer and embryo about $10 \%$ by weight of brown rice before polishing. The sample of this bran was collected from medium scale rice milling which spread in most areas in Egypt. In medium scale rice milling, brown rice is processed by polishing (rubbing) the kernels in one stage, the bran was collected together.

2. Polish or white bran (whitish color): The white bran from white polishing and polishing that has whitish color, which consists of some portion of remainder bran, some portion of subaleurone layer and starchy endosperm about 2-3\% by weight of brown rice. The sample of this bran was collected from large scale commercial rice milling in Kafr elsheikh City during polishing stage. During commercial milling, brown rice is processed by polishing (rubbing) the kernels four times; the bran was collected for this study after two rubbing stages.

The chemical composition of two rice bran components was analyzed by using $\boldsymbol{A O A C ( 2 0 0 3 )}$ method in the laboratory of Food Tech. Dep., Faculty of Agric., Kafrelsheikh University as indicated in Table 1. 
Table 1: Chemical composition of two rice bran components.

\begin{tabular}{|ll|c|c|}
\hline \multicolumn{2}{|c|}{ Constituents } & $\begin{array}{c}\text { Dark bran } \\
(\mathbf{1 1 . 4} \%, \text { M.C. })\end{array}$ & $\begin{array}{c}\text { White bran } \\
(\mathbf{1 1 . 1} \%, \text { M.C. })\end{array}$ \\
\hline Crude protein $(\% \mathrm{~N} \times 6.25)$ & $12.3-15.2$ & $11.6-13.4$ \\
\hline Crude fat $(\%)$ & $15.2-19.7$ & $10.8-13.4$ \\
\hline Crude fiber $(\%)$ & $7.2-12.3$ & $3.3-4.2$ \\
\hline Carbohydrate $\quad(\%)$ & $30.1-51.3$ & $50.1-54.0$ \\
\hline Minerals $\quad(\mathrm{mg} / \mathrm{g})$ & $78.3-332.2$ & $43.5-146.7$ \\
\hline Vitamin $\quad(\mu \mathrm{g} / \mathrm{g})$ & $260.8-516.3$ & $216.7-422.4$ \\
\hline Crude ash $(\%)$ & $6.7-10.1$ & $6.2-6.8$ \\
\hline
\end{tabular}

\section{Equipment:}

An expression machine for oil extraction from flax linseed (expeller), which was developed by Al-Ashry(1999) and modified by Matouk $\boldsymbol{e t}$ al.(2009) was used for the work of this paper after modification of the outlet ring die and barrel design. The technical specifications of the pressing machine are shown in Table 2 and Figure 1.

Table 2: Technical specifications of the development pelleting machine:

\begin{tabular}{|c|c|}
\hline Item & Specifications \\
\hline Main Dimensions: & \\
\hline - Overall length, cm; & 136 \\
\hline Overall width, cm; & 61.5 \\
\hline - $\quad$ Overall height, cm; & 155 \\
\hline - Total mass, kg. & 513 \\
\hline Screw: & \\
\hline - Length, cm; & 56 \\
\hline Diameter, $\mathrm{cm}$ & 10 \\
\hline Pitch (trough width), cm; & 5 \\
\hline Peak height (trough depth), $\mathrm{cm}$; & 1.5 \\
\hline - Flights No.; & 10 \\
\hline Hopper: & \\
\hline $\begin{array}{l}\text { - Length, } \mathrm{cm} \text {; } \\
\text { - } \quad \text { Average diameter, cm: }\end{array}$ & $\begin{array}{l}35 \\
30\end{array}$ \\
\hline $\begin{array}{l}\text { Power source: } \\
\quad \text { - Power req., HP, kW: }\end{array}$ & $\begin{array}{c}\text { Three phase electric } \\
\text { Motor, } \\
10(7.5)\end{array}$ \\
\hline
\end{tabular}


7. Meal discharge end

8. Horizontal shaft

9. Reduction speed unit (gear

box)

10. Driving pulley

11. V-Belty

12. Motor

13. Motor pulley

14. Bearing

15 . Sliding plate

16. Cage bracket

17. Oil outlet

18. Frame (main frame)

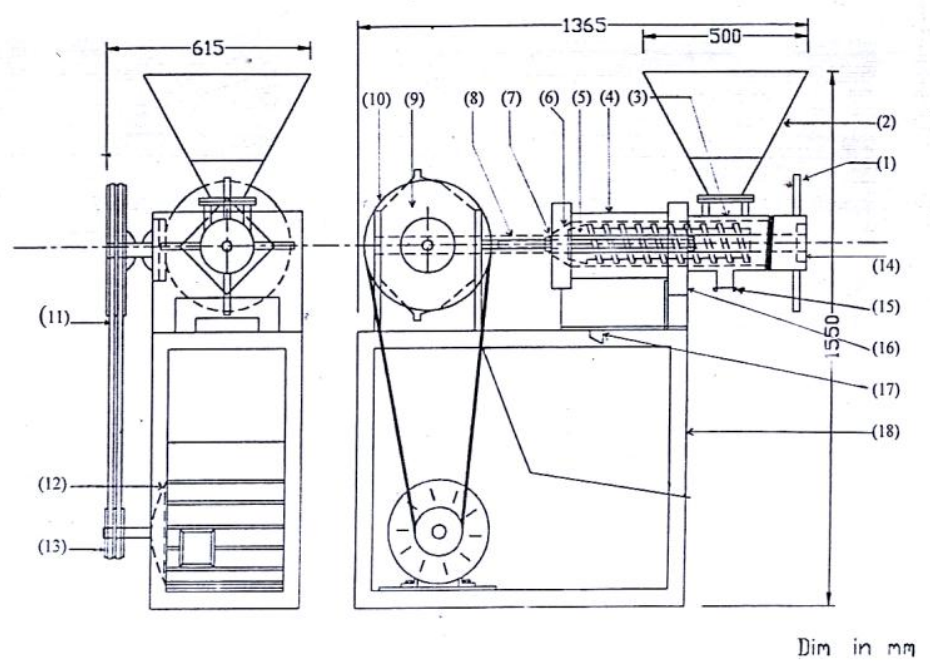

Elevation

Side view

Figure 1: Schematic diagram of the manufactured expression machine.

\section{Machine Modification for rice bran pelleting:}

The original die outlet head has a chuck like outlet that changed and replaced by an outlet ring die have 16,14 and 12 round holes for forming rice bran pellets at different diameters $(6,8$ and $10 \mathrm{~mm}$, respectively) by extrusion process, where the function of the chuck of the original outlet die to permit a final adjustment of pressure and capacity. Also, the barrel used for extraction of rice bran oil was modified to fit with rice bran pelleting. The clearance between the flat steel bars inside the barrel (cage) was eliminated and the bars also sloped towards the die hole of extruder by reducing the bars cross section of the bar set raised the compression action of the screw towards the die hole of extruder to increase the extruder die work area as indicated in Figure 2.

\section{Experimental treatments}

The experimental treatments, included four levels of screw speed $(0.262$, $0.524,0.786$ and $1.05 \mathrm{~m} / \mathrm{s}$.), three levels of die hole diameter of extruder $(6,8$, and $10 \mathrm{~mm})$, three levels of moisture content $(11.4,14.2$ and $16.1 \%$, wet basis) and two different types of bran (white bran and dark bran ). 

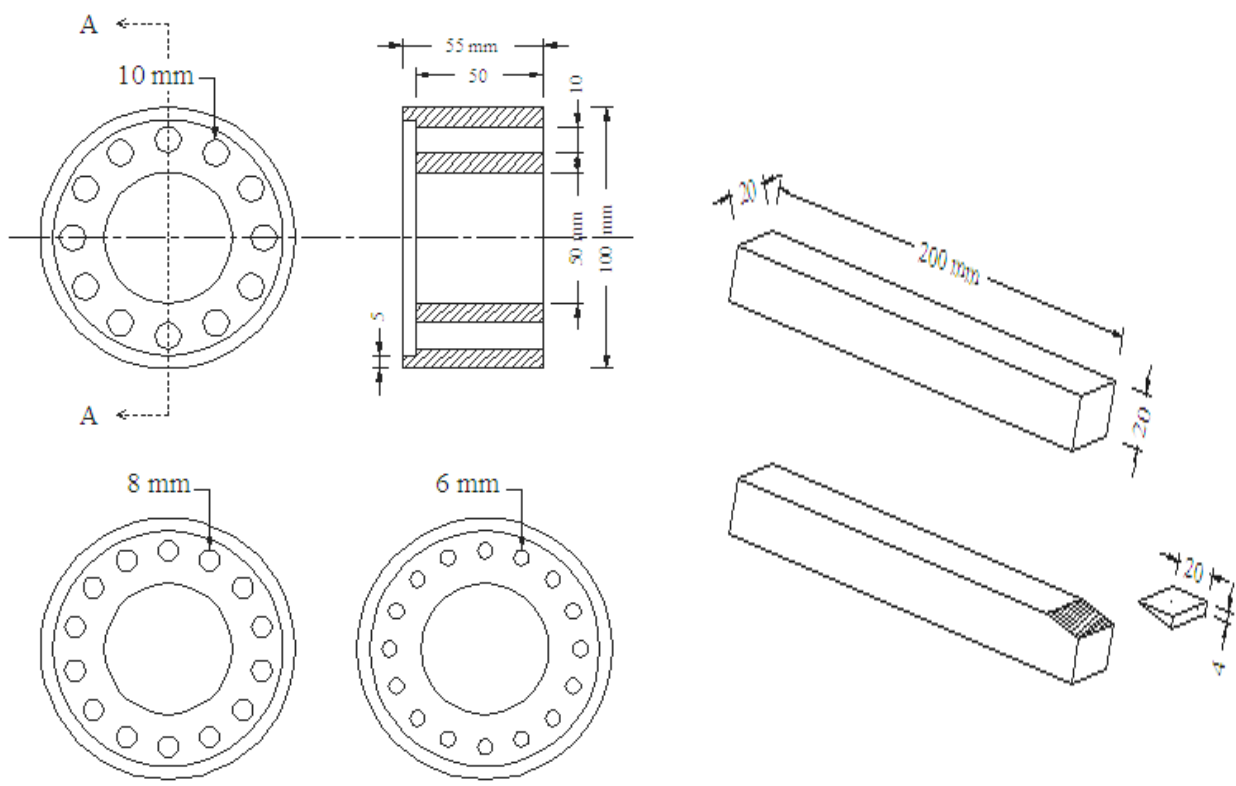

Figure 2: Cross section of the modified barrel and the die holes diameters of extruder.

\section{Test procedure and measurements:}

Before each experiment, rice bran was taken from freezing room and left at room temperature until reached the room temperature, and the experimental run as follow:

1. Before pelleting operation the hopper was filled with rice bran sample.

2. The pelleting machine was run.

3. The consumed time from the instant of dropping until the instant of complete discharge was measured.

4. Samples were taken periodically from the machine outlet placed in ambient air to natural cooling and drying.

5. After average of three replicated of this procedure was taken with two rice bran components (white bran and dark bran) at various moisture content, the amount of rice bran pellet was determined. Then the machine productivity, $\mathrm{kg} / \mathrm{h}$. Power consumption, $\mathrm{kW}$ and specific energy requirement, $\mathrm{kW} . \mathrm{h} / \mathrm{ton}$ were estimated for each test. The quality of the rice bran pellets (durability index, $\%$ and hardness, $\mathrm{N}$ ) was also evaluated. 


\section{Measurements:}

\section{Moisture content of rice bran:}

The standard air oven method using five grams sample placed in air oven at $135{ }^{\circ} \mathrm{C}$ for $3 \mathrm{~h}$. used for measuring bran moisture content as recommended by $A O A C(2003)$.

\section{Machine productivity, $\mathrm{kg} / \mathrm{h}$ :}

Raw material was manually fed into the feed hopper at a uniform rate to prevent blockage at the entrance to the barrel. During experimentation, extrudates samples were collected at 30-sec intervals and the mass flow rate through the extruder was then calculated, $\mathrm{kg} / \mathrm{h}$ as follows:

$$
\text { Machine Productivity, } \mathrm{kg} / \mathrm{h}=M_{p} / T \text { x } 3.6
$$

Where: $M_{p}=$ pellets mass, $\mathrm{g}, \quad T=$ consumed time, $\mathrm{s}$

\section{Energy requirement, $\mathbf{k W}$ :}

The electric power consumption for each test was measured by using an electrical meter, model (GG150E) having an accuracy of $1 \%$, which connected at the source of power supply. Then the actual power of the machine, P was estimated according to Uppal (1984) as follows:

$$
P=\sqrt{ } 3 \cdot I_{L} \cdot N_{L} \cdot \eta \cdot \cos \varphi / 1000
$$

Where: $\mathrm{I}_{\mathrm{L}}=$ electric current, ampere,

$\mathrm{N}_{\mathrm{L}}=$ electric potential, volt, being equal to 360 volt,

$\eta=$ mechanical efficiency $(95 \%)$, and

$\operatorname{Cos} \varphi=$ power factor (0.85).

\section{Specific energy requirements $(\mathrm{kW} . \mathrm{h} / \mathrm{ton})$ :}

It was evaluated by calculate the consumed power, $\mathrm{kW}$ then divided by the machine productivity, ton/h:

Energy requirements, $\boldsymbol{k W}$.h/ton =Power/Extruder productivity

\section{Rice bran pellets quality:}

1. Pellet durability index, \%: It was determined according to $\boldsymbol{A S A E}$ (2004). Extrudates (200g) were tumbled inside a pellet durability tester, model (Seedburo) for $10 \mathrm{~min}$ and sieved through a No. 6 screen. Pellet durability index was calculated as follow: 
PROCESS ENGINEERING

$$
\text { Durability }=\left(M_{a} / M_{b}\right) \times 100, \quad(\%)
$$

Where: $M_{a}$ and $M_{b}$ are mass (g) of pellets retained on the screen after and before tumbling, respectively.

2. Pellets hardness: A portable hardness Tester, model (174866 Kiyo Seisakusho, LT. D.) was used to determine the pellets rupture force in Newton.

\section{Statistical Analysis:}

The multiple linear regression analysis was employed in this experimental work to examine and assess the effect of operating parameters on the extruder productivity, energy requirements and pellets quality of rice bran components.

\section{RESULTS AND DISCUSSIONS}

The objectives of this study were to examine and analyze the effects of four screw revolving speed $(0.262,0.524,0.786$ and $1.05 \mathrm{~m} / \mathrm{s})$, three die hole diameter $(6,8$ and $10 \mathrm{~mm})$ as well as three levels of moisture content $(11.1,14.2$ and $16.1 \%$, ) during extrusion process on the machine performance and the resulting extrudate properties (pellets durability index, $\%$ and hardness, $\mathrm{N}$ ) of two rice bran components (white and dark bran).The results revealed that the high content of oil in the bran acts as a lubricant, making addition of moisture unnecessary to formatted the rice bran pellets.

\section{Effect of Operating Parameters on Extruder Productivity, kg/h:}

From the results obtained in Figure 3, it noticed that, the extruder productivity was increased with increasing screw speed and die hole diameter, while it was decreased with increasing moisture content of two rice bran components. At the same hole diameter $(10 \mathrm{~mm})$, the extruder productivity of white bran was increased by $30.3,35.4$ and $25.8 \%$ when screw speed increased from 0.262 to $1.05 \mathrm{~m} / \mathrm{s}$ at bran moisture contents $11.4,14.2$ and $16.1 \%$, respectively. Also, at the same screw speed $(0.786$ $\mathrm{m} / \mathrm{s}$ ), the productivity was increased by $26.1,22.5$ and $26.0 \%$ when the 
White bran
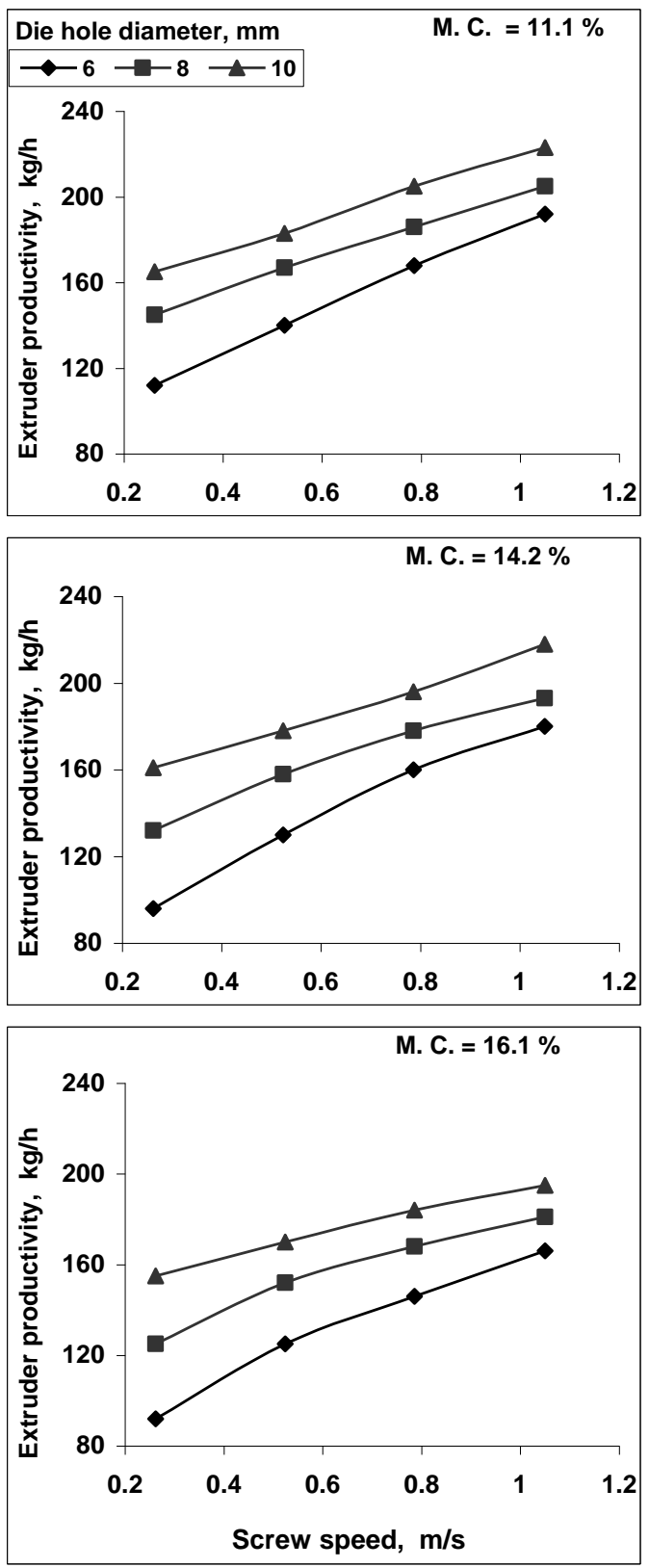

Dark bran
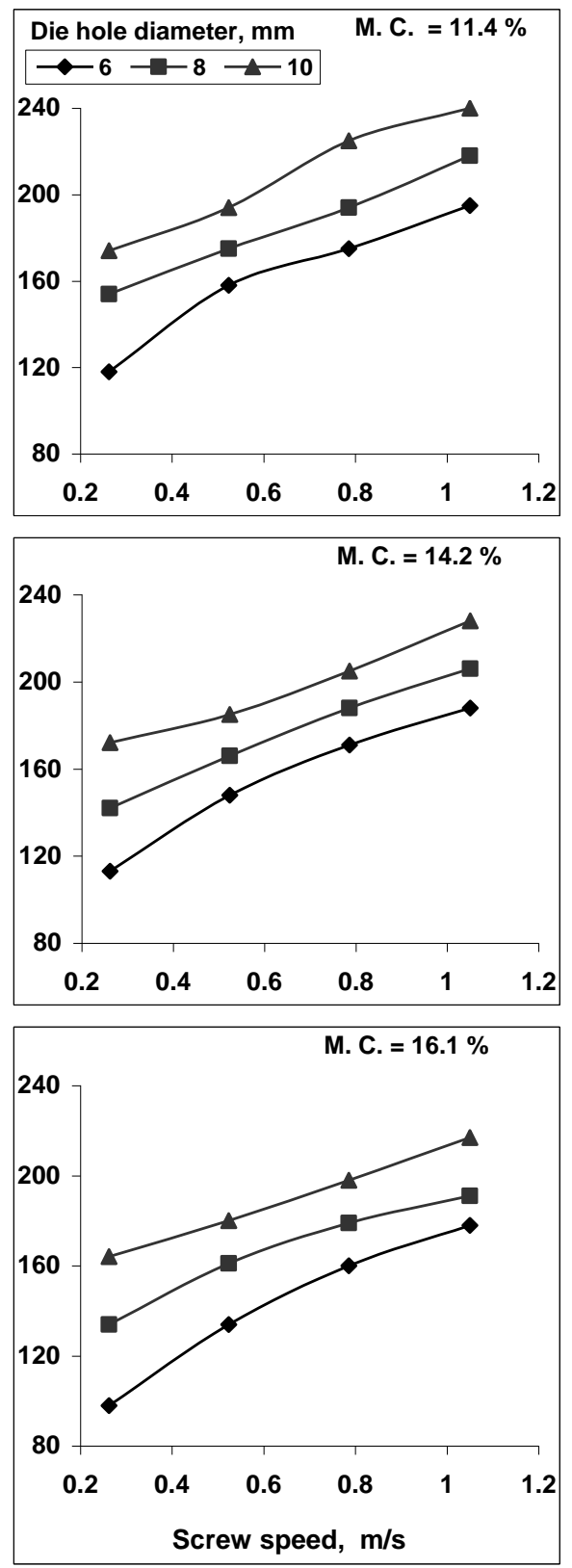

Figure (3): Effect of screw speed and die hole daimeter on the extruded pellets productivity for two rice bran componants at various moisture contents. 
die hole diameter increased at 6,8 and $10 \mathrm{~mm}$, with the same bran moisture content mentioned above. While, at the same screw speed $(0.786 \mathrm{~m} / \mathrm{s})$ and die hole diameter $(6 \mathrm{~mm})$, the extruder productivity was decreased by $4.8 \%$ and $8.75 \%$ with increasing white bran moisture content from 11.1 to $14.2 \%$ and from 14.2 to $16.1 \%$, respectively. The same trend was noticed with various operating parameters of dark bran, but the productivity was higher value by about $12 \%$ than the productivity of white bran due to the high content of oil in the dark bran acts as a lubricant. This increase in productivity of pelletizer with the increase of screw speed may be due to the increase of bran quantities which passed through the extrusion unit and expelled from the die hole at the same time. This behavior was expected because drag flow in extruders has been shown to be directly proportional to screw speed and higher screw speeds generally result in higher mass flow rates as reported by Chevanan et al.(2010). Also, the productivity was increased with the increase of die hole diameters due to the increase of output area that help the pellets to move out the die holes quickly, resulting remarkable decrease in treatment consumed time. While, decreasing extruder productivity with increasing bran moisture content may be due to the increase of bran adhesion over the screw with increasing screw revolving speed.

Effect of Operating Parameters on Extruder Power Consumption, kW and Specific Energy Requirements, kW. h/ton:

The energy requirements of pellets depend theoretically on consumed power and productivity, while depend practically on the effect of operating parameters such as screw speed and die hole diameter of extruder as well as bran components and its moisture content. The results in Figure 4 and 5 show that power consumption and consequently specific energy requirements was increased with increasing screw speed and bran moisture contents. While, the power consumption and energy requirements was decreased when increasing die hole diameter. At the same die hole diameter $(10 \mathrm{~mm})$, the power consumption was increased from 2.62 to $5.61 \mathrm{~kW}$, from 2.75 to $5.85 \mathrm{~kW}$ and from 2.88 to $6.4 \mathrm{~kW}$ when screw speed of extruder increased from 0.262 to $1.05 \mathrm{~m} / \mathrm{s}$ at white bran moisture contents 11.1, 14.2 and $16.1 \%$, respectively. Also, at the 
White bran
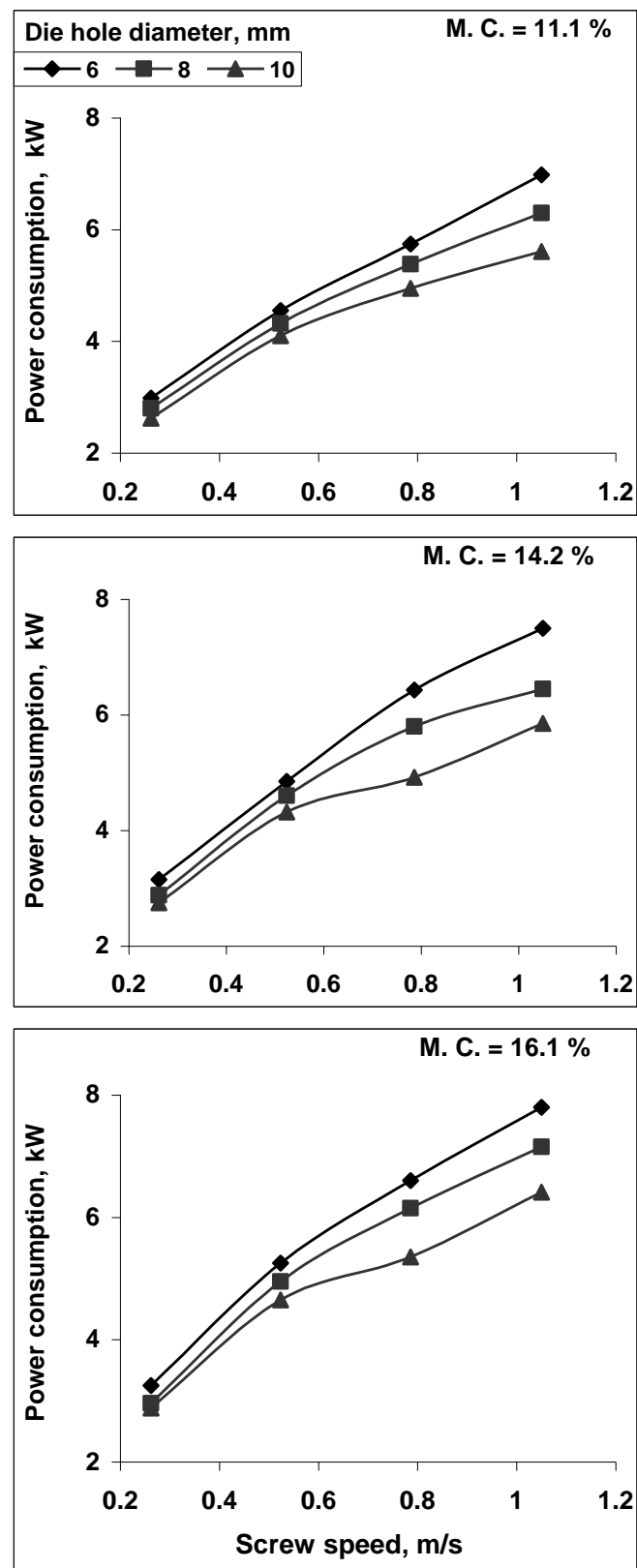

Dark bran

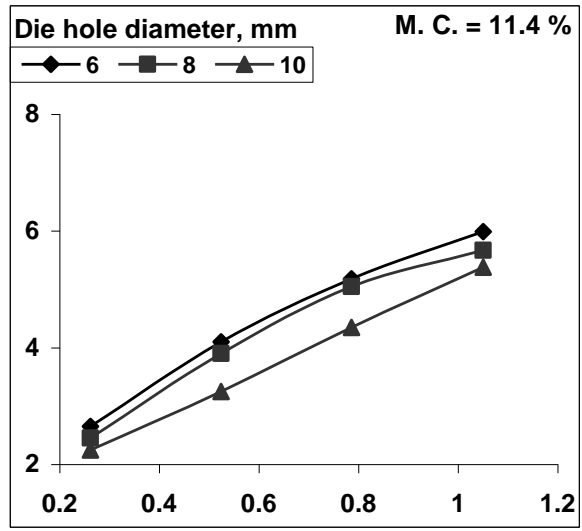

M. C. $=14.2 \%$

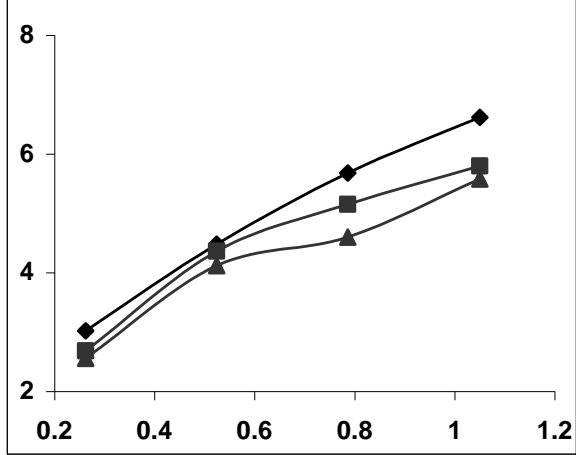

M. C. $=16.1 \%$

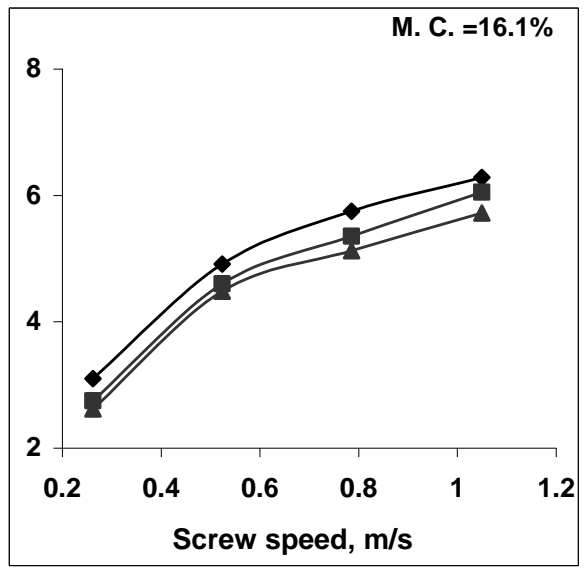

Figure (4): Effect of screw speed and die hole daimeter on extruder power consumption for two rice bran componants at various moisture contents. 
White bran
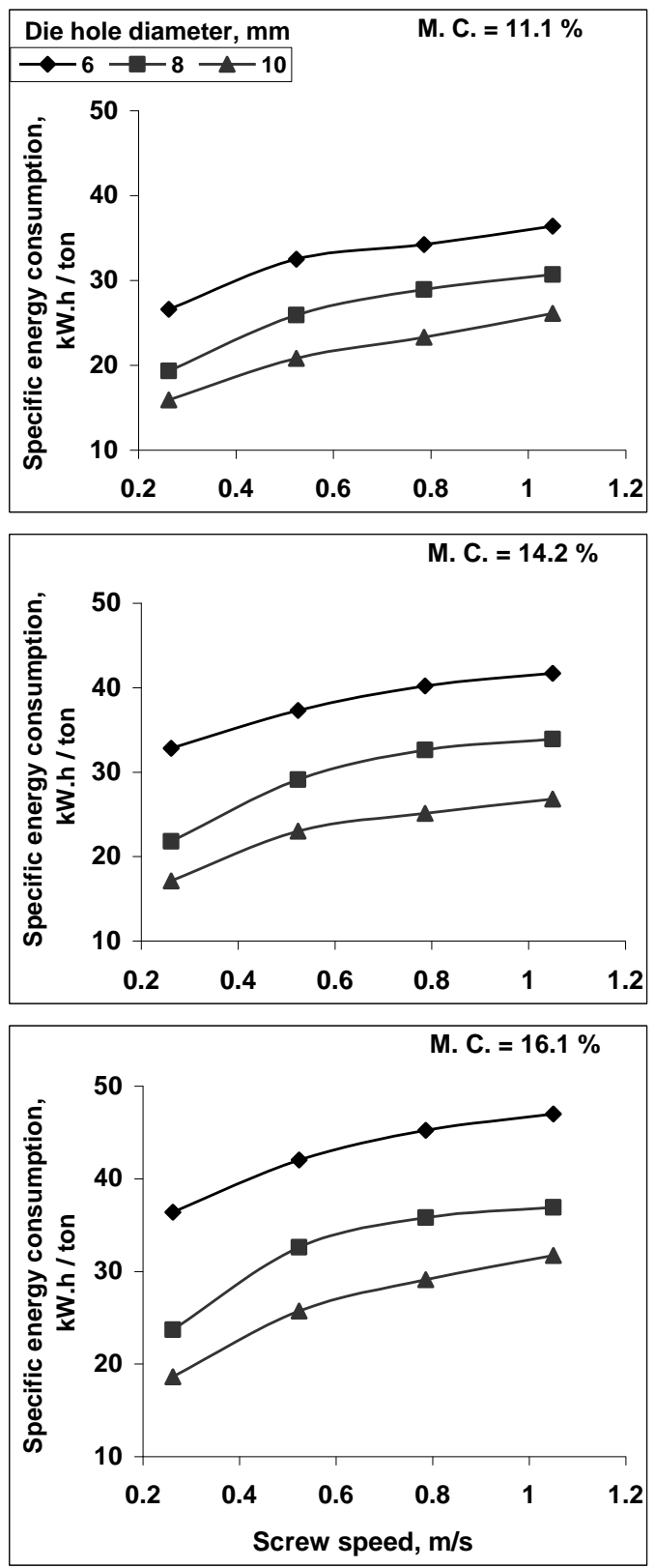

Dark bran
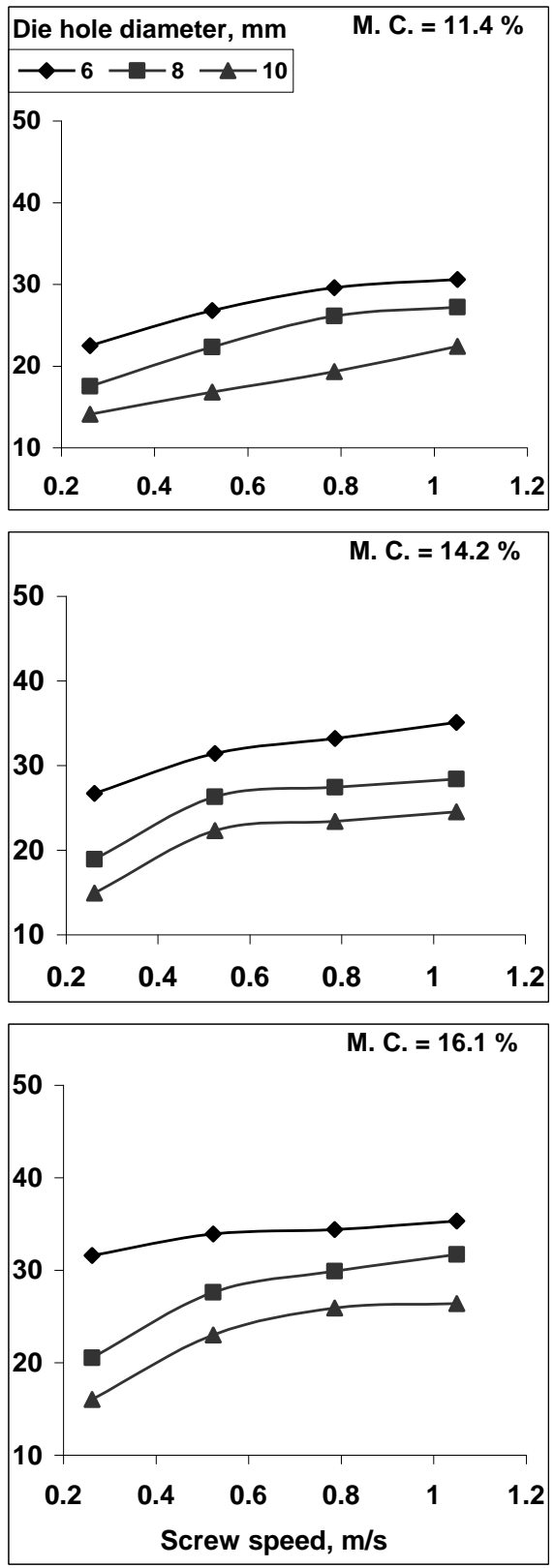

Figure (5): Effect of screw speed and die hole daimeter on specific energy consumption for two rice bran componants at various moisture contents. 
same screw speed $(0.786 \mathrm{~m} / \mathrm{s})$, it was decreased from 5.74 to $4.96 \mathrm{~kW}$, from 6.43 to $5.8 \mathrm{~kW}$ and from 6.6 to $5.345 \mathrm{~kW}$ with increasing die hole diameter from 6,8 and $10 \mathrm{~mm}$ at the same moisture contents mentioned above as shown in Figure 4. Consequently, at the same die hole diameter $(10 \mathrm{~mm})$, the energy requirements was increased by $64.1,56.7$ and $70.4 \%$ when screw speed of extruder increased from 0.262 to $1.05 \mathrm{~m} / \mathrm{s}$ with white bran moisture contents of 11.1, 14.2 and $16.1 \%$, respectively. Also, at the same screw speed $(0.786 \mathrm{~m} / \mathrm{s})$, it was decreased by $31.2,37.8$ and $35.6 \%$ with die hole diameters 6,8 and $10 \mathrm{~mm}$, respectively, at the same white bran moisture contents mentioned above as shown in Figure 5. The same trend was noticed with various operating parameters of dark bran, while the power consumption was lower value by about $7.25 \%$ and energy requirements lower value by $8 \%$ than the values obtained with white bran. The increase in energy requirements by increasing screw speed could be due to the high increase required power and at the same time the slower increase in production rate was occurred. Also, the increase in energy requirements by increasing bran moisture contents could be due to the increase of bran adhesion over the screw and more torque required rotating the extruder screw as reported by Chevanan et al. (2010). Meanwhile, the decrease of energy requirements by increasing die hole diameter may be due to the increase of output area that caused a decrease in the pressure load and required power, and increase the treatment production rate in the same time.

\section{Effect of Operating Parameters on Rice Bran Pellets Durability, \%:}

The result in Figure 6 shows that pellets durability was increased with increasing screw speed and bran moisture contents. While, it was decreased when increasing die hole diameter of extruder. At the same die hole diameter $(10 \mathrm{~mm})$, durability was increased by $31.7,23.5$ and $18.9 \%$ when screw speed increased from 0.262 to $1.05 \mathrm{~m} / \mathrm{s}$ at white bran moisture contents $11.1,14.2$ and $16.1 \%$, respectively. Also, at the same screw speed $(0.786 \mathrm{~m} / \mathrm{s})$ and die hole diameter $(10 \mathrm{~mm})$, the durability was increased by $10.8 \%$ when increasing moisture content from 11.4 to $16.1 \%$. Meanwhile, at the same screw speed $(0.786 \mathrm{~m} / \mathrm{s})$, the durability 
was decreased by $9.5,9.1$ and $8.7 \%$ when the die hole diameter increased from 6,8 and $10 \mathrm{~mm}$, respectively with the same moisture content

\section{White bran}
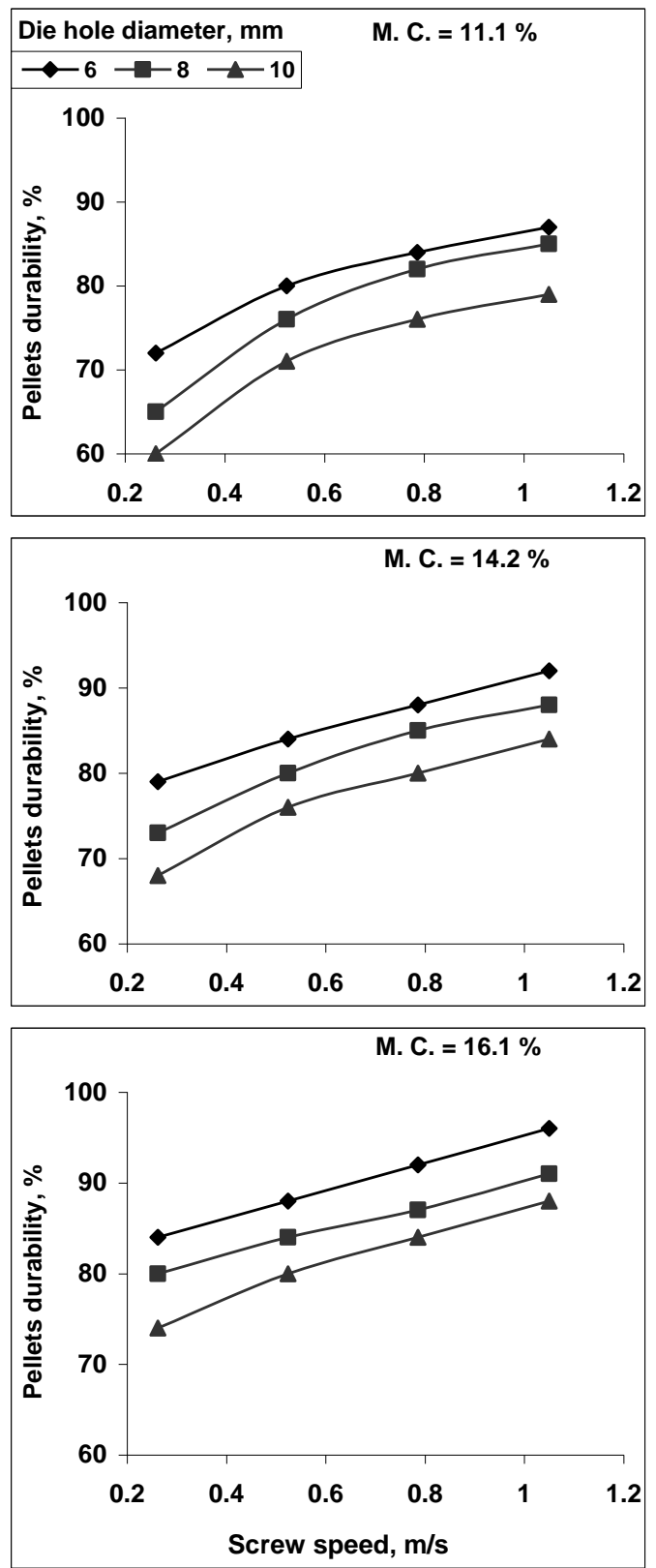

\section{Dark bran}
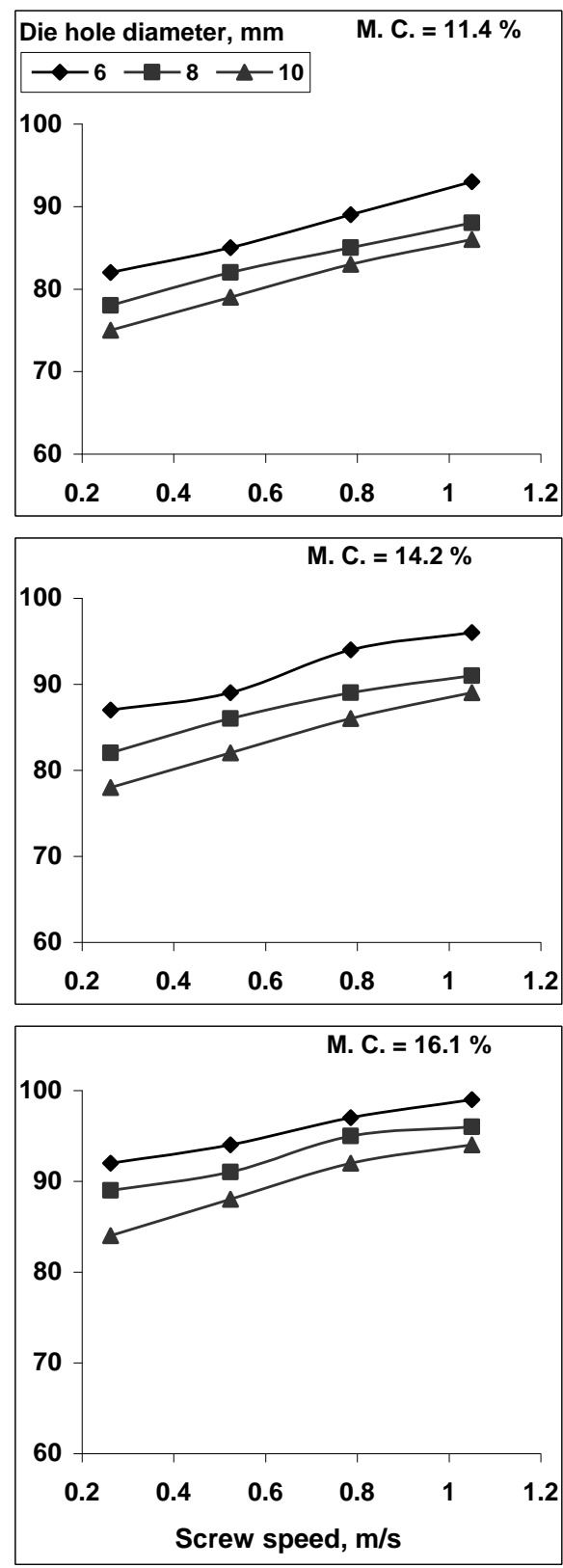

Figure (6): Effect of screw speed and die hole daimeter on the extruded pellets durability for two rice bran componants at various moisture contents. 
mentioned above. The same trend was noticed with various operating parameters of dark bran, but the pellets durability was higher value by about $12.3 \%$ than the values of durability of white bran. The increase in the durability of dark bran may be due to the high content of crude fat and starch. The high content of crude fat in the dark bran acts as a lubricant and the starch gelatinization plays an important role in determining final extrudates properties as revealed by Lam and Flores (2003). They reported that, binding of the fines in the pellet is assisted by starch gelatinization during heating of the extruded ingredients. These results were agreed with the data obtained by Shukla et al.(2005) and Chevanan et al.(2007). They reported that changing the level of moisture content of the ingredient blends had a significant effect on extrudates pellets durability index. They also reported that increasing the moisture content from 15 to $25 \%$ resulted in an $8.7 \%$ increase in extrudates pellets durability index. The increase of pellets durability by increasing screw speed and bran moisture content could be due to the increase in pellets compression in the die zone, as well as increasing the temperature which remove the moisture from the cells between the granules, that make the pellets too hard with high resistance against cracking and breakage. Meanwhile, as noticed by Tumuluru et al. (2010), the decrease of pellets durability index by increasing die hole diameter of extruder could be due to increasing the output area which decreases pressure in die extrusion, it means low level of pellets compaction and high amount of air between the bran granules.

\section{Effect of Operating Parameters on Rice Bran Pellets Hardness, N:}

Hardness of pellets was measured to find out its ability to break-up. Figure 7 shows that, at the same die hole diameter $(10 \mathrm{~mm})$, the pellets hardness was increased by $60.1,84.4$ and $74.5 \%$ when screw speed increased from 0.462 to $1.05 \mathrm{~m} / \mathrm{s}$ at white bran moisture contents 11.1 , 14.2 and $16.1 \%$, respectively. Also, at the same screw speed $(0.786 \mathrm{~m} / \mathrm{s})$ and die hole diameter $(10 \mathrm{~mm})$, the pellets hardness was increased by $24.3 \%$ when increasing bran moisture content from 11.1 to $16.1 \%$. Meanwhile, at the same screw speed $(0.786 \mathrm{~m} / \mathrm{s})$, the hardness was 
decreased by $34.8,23.9$ and $33.9 \%$ when the die hole diameter of extruder increased at 6,8 and $10 \mathrm{~mm}$, respectively with the same

White bran
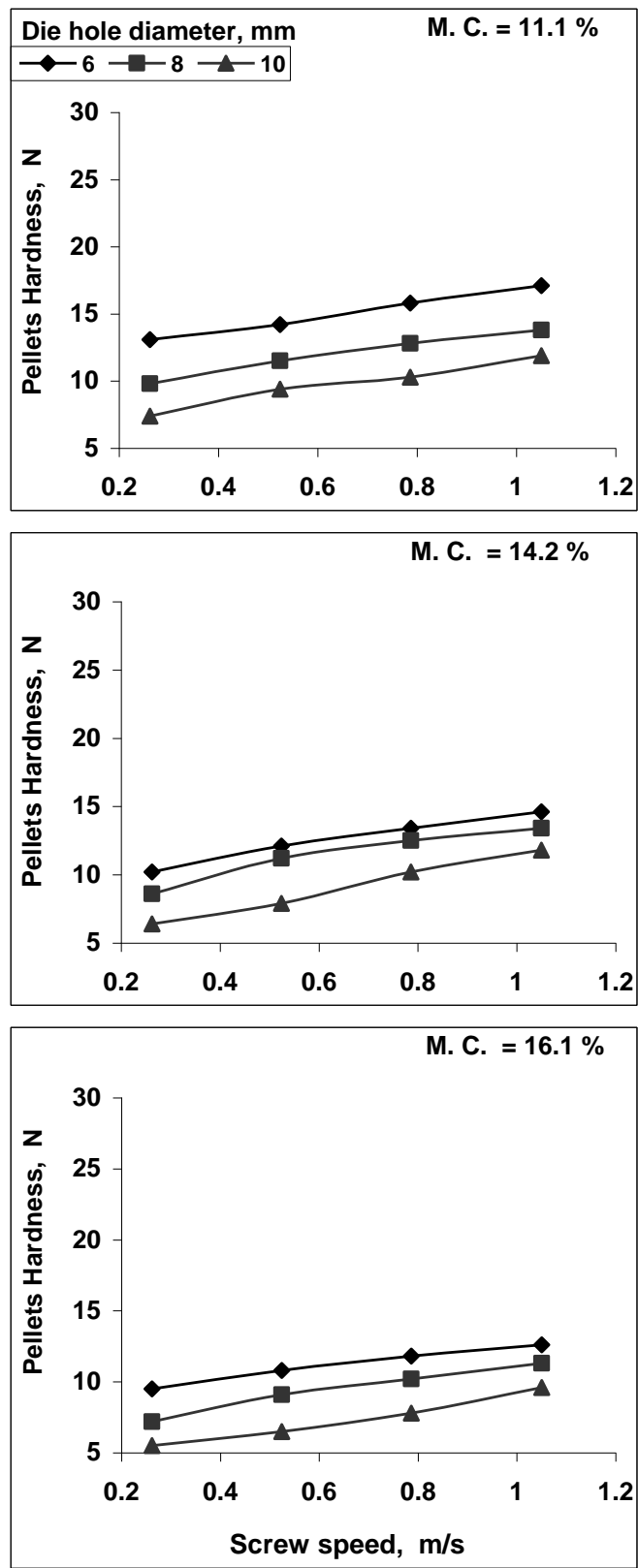

\section{Dark bran}

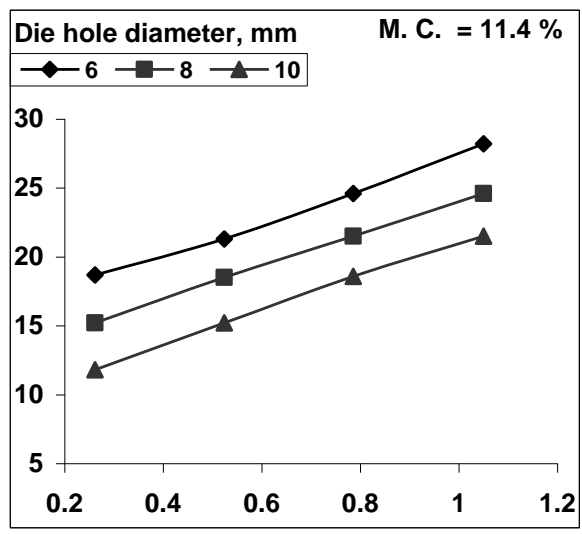

M. C. $=14.2 \%$
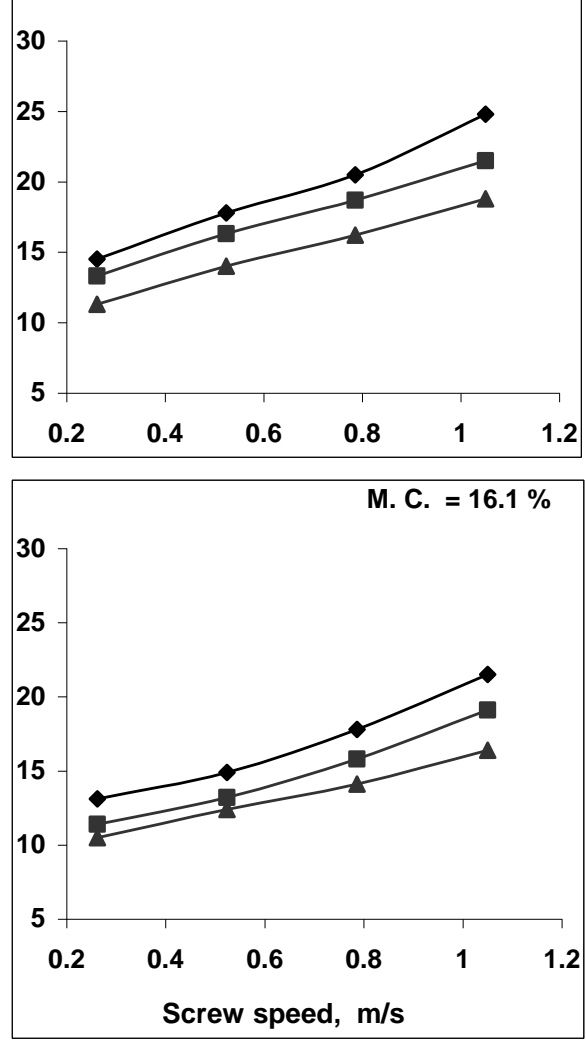

Figure (7): Effect of screw speed and die hole daimeter on the extruded pellets hardness for two rice bran componants at various moisture contents. 
moisture content mentioned above. The increase of pellets hardness with increasing screw speed may be due to the increase in pellets compression in the die zone, as noticed with pellets durability. While the decrease of hardness with the increase of bran moisture content and die hole diameter may be due to the applied pressure was not enough to compact the pellets and less friction suffered by the compact materials through the 8 and 10 $\mathrm{mm}$ die hole diameter. The same trend was noticed with various operating parameters of dark bran, but the hardness was higher value by about $65.2 \%$ than the values of hardness of white bran. The increase in the pellets hardness of dark bran may be due to the protein neutralization and starch gelatinization. It was proposed that mechanical shearing in the pellet die, which causes frictional heating, was the cause for the extensive gelatinization. This result indicated that the amount of fines and dust that may be produced during handling will be minimum for the small pellets in diameter as well as dark rice bran component.

\section{The Relation between the Extruder Performance, Pellets Quality of} Rice Bran and Operating Parameters:

The relations between the extruder performance (productivity, $\mathrm{kg} / \mathrm{h}$; power consumption, $\mathrm{kW}$ and specific energy consumption, $\mathrm{kW} . \mathrm{h} /$ ton) and pellets quality (durability index, $\%$ and hardness, $\mathrm{N}$ ) as dependent variables and screw revolving speed, $\mathrm{S}, \mathrm{m} / \mathrm{s}$; die hole diameter of extruder, $\mathrm{D}, \mathrm{mm}$; rice bran moisture content, $\mathrm{M}, \%$ and rice bran components (white and dark bran) as independent variables were analyzed and the results expressed in the following formulas:

\section{For white bran pellets:}

$$
\begin{aligned}
\text { 1-Productivity, } \quad \mathbf{k g} / \mathbf{h}= & \mathbf{7 0 . 9 9}+\mathbf{8 0 . 5 5} \mathrm{S}+\mathbf{1 0 . 9 3} \mathrm{D}-\mathbf{3 . 8 0} \mathrm{M} ; \\
& \left(\mathrm{r}^{2}=0.96, \mathrm{~S}_{\mathrm{E}}=5.99\right), \\
\text { 2-Power consumption, } \mathbf{k W}= & \mathbf{2 . 1 2}+\mathbf{4 . 7 1} \mathrm{S}-\mathbf{0 . 2 2} \mathrm{D}+\mathbf{0 . 1 1} \mathrm{M} ; \\
& \left(\mathrm{r}^{2}=0.96, \mathrm{~S}_{\mathrm{E}}=0.32\right),
\end{aligned}
$$

3-Specific energy consumption, $\mathrm{kw} . \mathrm{h} / \mathrm{ton}=\mathbf{3 0 . 5 8}+\mathbf{1 3 . 6 6} \mathrm{S}-3.53 \mathrm{D}+1.37 \mathrm{M}$;

$$
\left(\mathrm{r}^{2}=0.94, \mathrm{~S}_{\mathrm{E}}=1.96\right) \text {, }
$$

$$
\begin{aligned}
& \text { 4-Durability, } \quad \% \quad=61.41+18.83 \mathrm{~S}-2.22 \mathrm{D}+1.82 \mathrm{M} \text {; } \\
& \left(\mathrm{r}^{2}=0.96, \mathrm{~S}_{\mathrm{E}}=1.73\right) \text { and } \\
& \text { 5-Hardness, } \quad \mathrm{N}=23.63+5.40 \mathrm{~S}-1.05 \mathrm{D}-\mathbf{0 . 5 7} \mathrm{M} \text {; } \\
& \left(r^{2}=0.98, S_{E}=0.60\right) \text {. }
\end{aligned}
$$

Where: $r^{2}=$ the coefficient of determination, $S_{E}=$ the standard error. 


\section{For dark bran pellets:}

$$
\begin{aligned}
& \text { 1-Productivity, } \quad \mathbf{k g} / \mathbf{h}= \mathbf{8 4 . 5 4}+\mathbf{8 3 . 1 4} \mathrm{S}+\mathbf{1 1 . 3 4} \mathrm{D}-\mathbf{3 . 9 0} \mathrm{M} ; \\
&\left(\mathrm{r}^{2}=0.98, \mathrm{~S}_{\mathrm{E}}=5.98\right) \\
& \text { 2-Power consumption, } \mathbf{k W}=\mathbf{1 . 6 5}+\mathbf{4 . 0 3} \mathrm{S}-\mathbf{0 . 1 6} \mathrm{D}+\mathbf{0 . 1 1} \mathrm{M} ; \\
&\left(\mathrm{r}^{2}=0.96, \mathrm{~S}_{\mathrm{E}}=0.28\right)
\end{aligned}
$$

3-Specific energy consumption, kw.h/ton $=\mathbf{2 4 . 9 9}+\mathbf{1 0 . 8 2} \mathrm{S}-\mathbf{2 . 5 5} \mathrm{D}+\mathbf{1 . 0 1} \mathrm{M}$;

$$
\left(r^{2}=0.93, S_{E}=1.62\right) \text {, }
$$

4-Durability,

$$
\begin{gathered}
\%=\mathbf{6 9 . 8 7}+\mathbf{1 2 . 2 6} \mathrm{S}-\mathbf{1 . 7 1} \mathrm{D}+\mathbf{1 . 6 9} \mathrm{M} ; \\
\left(\mathrm{r}^{2}=0.96, \mathrm{~S}_{\mathrm{E}}=1.23\right) \text { and }
\end{gathered}
$$

5-Hardness,

$$
\begin{gathered}
\mathbf{N}=\mathbf{3 3 . 4 3}+\mathbf{1 0 . 7 9} \mathrm{S}-\mathbf{1 . 1 9} \mathrm{D}-\mathbf{0 . 9 8} \mathrm{M} ; \\
\left(\mathrm{r}^{2}=0.98, \mathrm{~S}_{\mathrm{E}}=0.81\right) .
\end{gathered}
$$

Where: $r^{2}=$ the coefficient of determination, $S_{E}=$ the standard error.

From these equations, it can be seen that there is a directly proportion between pellets productivity and both screw revolving speeds and die hole diameter of extruder. While, an inversely proportion was found between productivity and moisture contents of two rice bran components as shown in Figure 3. Also, there are a direct proportion between power consumption, specific energy requirement and durability of rice bran pellets and both screw revolving speeds and moisture contents of two bran components and an inversely proportion with die hole diameter as indicated in Figure 4, 5 and 6. Meanwhile, there is an inversely proportion between pellets hardness and both die hole diameter and bran moisture contents. While, a direct proportion was found between pellet hardness and screw revolving speeds as resulted in Figure 7. The regression equations were highly accurate and can be used to predict the change of extruder performance and quality of rice bran pellets under different operating conditions.

\section{CONCLUSION}

1. At the same hole diameter $(10 \mathrm{~mm})$, the extruder productivity was increased by $30.3,35.4$ and $25.8 \%$, specific energy requirement by $64.1,56.7$ and $70.4 \%$, durability by $31.7,23.5$ and $18.9 \%$, hardness by $60.1,84.4$ and $74.5 \%$ when screw speed increased from 0.262 to $1.05 \mathrm{~m} / \mathrm{s}$ with white bran moisture content of $11.1,14.2$ and $16.1 \%$, respectively.

2. At the same screw speed $(0.786 \mathrm{~m} / \mathrm{s})$ and die hole diameter $(6 \mathrm{~mm})$, the extruder productivity was decreased by $10.2 \%$ and hardness by 
$24.3 \%$, while energy requirement increased by $24.9 \%$ and durability by $10.5 \%$ with increasing white bran moisture content from 11.1 to $16.1 \%$.

3. The same trend was noticed with dark bran, but the productivity, pellets durability and hardness was higher value by about $12 \%, 12.3$ and $65.2 \%$ than the values of white bran. While, specific energy requirements was lower value by $8 \%$ than the specific energy requirement value with white bran.

4. The regression equations were found and can be used to predict the change of extruder performance and quality of rice bran pellets under different operating conditions.

\section{RECOMMENDATION}

From this point, this machine can be used successfully to pellet not only rice bran but also many commodities including coal, wood chips, residues agriculture straw, fertilizer, orange and beet pulp, organic waste and dried manure.

\section{REFERENCES}

Abhay Sah, B. K.; D. Agrawal and L. S. Shukla (1983). Influence of pellet size on extraction rate of rice bran oil. JAOCS, 60(2): 465. Al-Ashry, A.S. (1999). Development of a simple machine for expression of some oilseeds. Ph. D. Thesis Faculty of Agric. Minofia Univ., Egypt.

AOAC International (2003). Official methods of analysis of AOAC international (17th ed.). Gaithersburg, Massachusetts, USA: AOAC International.

ASAE Standard (2004). American Society of Agricultural Engineers Standards, Engineering Practices, and Data. ASAE: St. Joseph, MI

Chevanan, N.; K. Muthukumarappan; K.A. Rosentrater and J. L. Julson (2007). Effect of die dimensions on extrusion processing parameters and properties of DDGS-based aquaculture feed. Cereal Chemistry, 84(4), 389-398.

Chevanan N.; K. A. Rosentrater and K. Muthukumarappan (2010). Effects of processing conditions on single screw extrusion of feed 
ingredients containing DDGS. Food Bioprocess Technology, 3:111-120.

Kaliyan N. and R.V. Morey (2007). Strategies to improve durability of switch grass briquettes. An ASABE paper number: 076182.

Kim, C.J.; S. M. Byum; H. S. Cheigh and T. w. Kwon (1987). Comparison of solvent extraction characteristics of rice bran pretreated by hot air drying, steam cooking and extrusion. JAOCS, 64(4): 514 -519.

Lam, C. D. and R. A. Flores (2003). Effect of particle size and moisture content on viscosity of fish feed. Cereal Chem, 80:2024.

Matouk, A M.; M. M. El-Koly; M. El-Sadawy and Y. T. Hendawy (2009). Rice bran oil extraction using an expeller machine. Misr J. Ag. Eng., 26(1): 324-342.

Motthew, T. B. (2009). Stabilized rice bran. Animal Nutrition Division for NutraCea. Mbutler@nutracea.com. Item number: 120474490207.

Orthoefer, F. T.(2005). Rice Bran Oil. Bailey's Industrial Oil and Fat Products, Sixth Edition, Six Volume Set. Edited by Fereidoo Shahidi. Copyright, John Wiley and Sons, Inc.

Shukla C. Y.; K. Muthukumarappan and J. L Julso. (2005). Effect of single screw extruder die temperature, amount of distillers dried grains with solubles (DDGS) and initial moisture content on extrudates. Cereal Chemistry: 82(1), 34-37.

Sokhansanj, S., S. Mani, X. Bi, P. Zaini and L. Tabil (2005). Binderless pelletization of biomass. Presented at the ASAE Annual International Meeting, July 17-20, 2005, Tampa, FL. ASAE Paper No. 056061. ASAE, 2950 Niles Road, St. Joseph, MI 49085-9659 USA.

Tangprawat, C. (2006). Determination of total lipid content and Gamaoryzanol in rice bran. M Sc. Thesis, Faculty of graduate studies. Mahidol University, Thailand.

Takeshita, Y. (1984). Model planning of overseas rice bran oil mill. Transactions of the Kokushikan Univ. Dept. of Engineering. 17: 80-89. 
Tumuluru, J. S.; L. Tabil; A. Opoku; M. R. Mosqueda and O. Fadeyi (2010). Effect of process variables on the quality characteristics of pelleted wheat distiller's dried grains with soluble. Biosystems Engineering, 105(4): 466-475.

Uppal, S. L. (1984). Electrical power. Published by 2-B Nath Market, Nai Srak, New Delhi, India.

Yasuhiko, T. and F. Iwata (1988). Recent technical advances in rice bran oil processing (II). About refining process. Transactions of the Kokushikan Univ. Faculty of Engineering, 21: 118 - 124.

\section{الملخص العربي}

\section{إنتاج مصبعات رجيع الأرز باستخدام وحدة الكبس المستمر المربي}

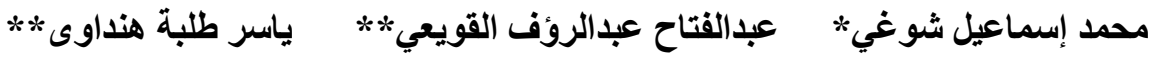

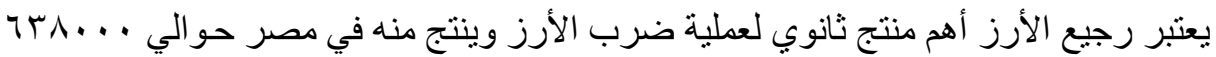

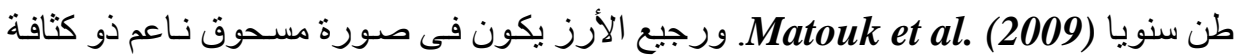

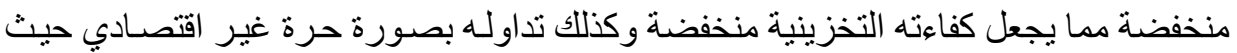

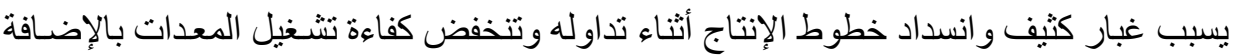

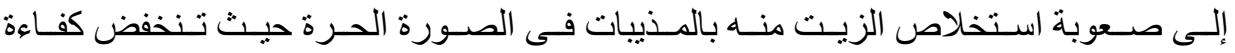

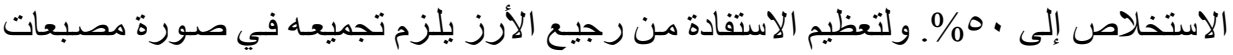

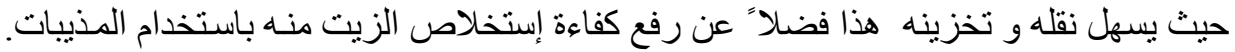

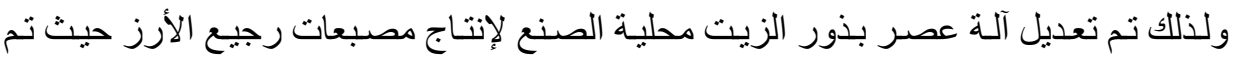

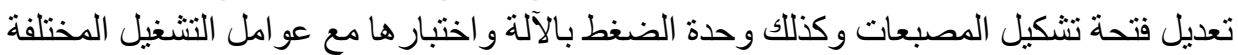
بغرض إنتاج مصبعات ذو جودة عالية مع خفض استهلاكل فئك الطاقة. أهداف البحث:

1. تعديل واختبار آلة عصر بذور الزيت محلية الصنع لإنتاج مصبعات رجيع الأرز لإستخدام هذه المصبعات فى إستخلاص الزيت منها بإستخدام المذيبات بكفاءة عالية الئه

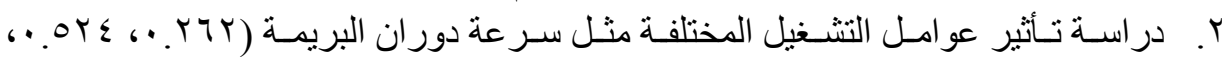

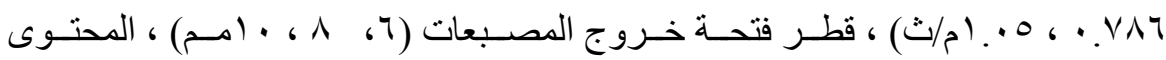

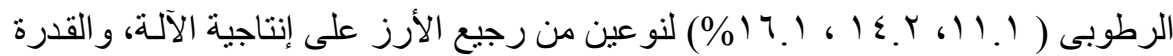

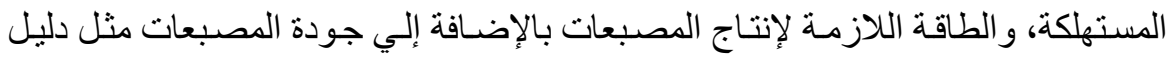
تحمل المصبعات للتصادم و الصلابة.

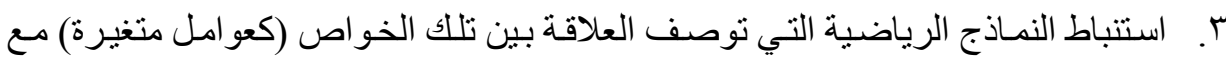
التغير فى سلوكيات التشغيل (كعو امل مستقلة) لنو عي رجيع الأرز تحت الدر اسة.

$$
\begin{aligned}
& \text { باحث أول بمعهة بحوث الهندة الزراعيةـ الدقي- جيزة - مصر. } \\
& \text { *:باحث بمعهد بحوث الهندسة الزراعيةـ الدقي - جيزة - مصر. - مصن. }
\end{aligned}
$$


أهم النتائج:

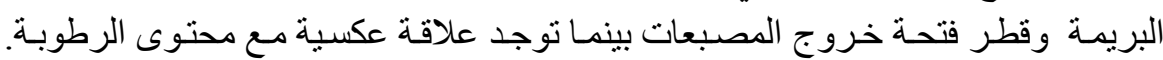

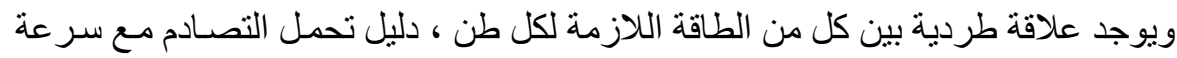

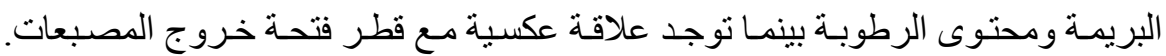

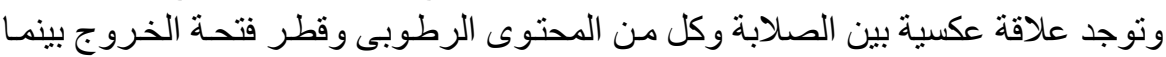

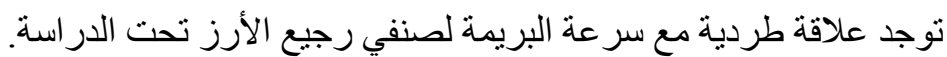

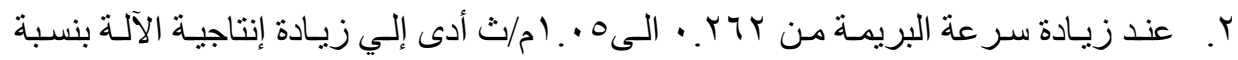

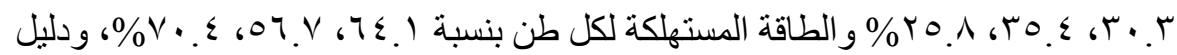

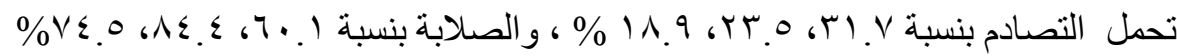

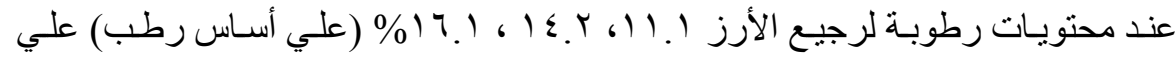
الترتيب.

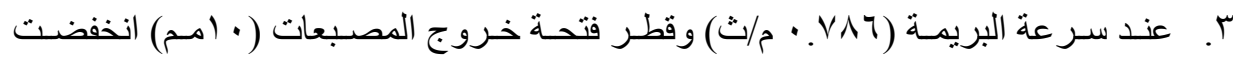

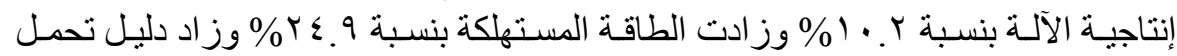

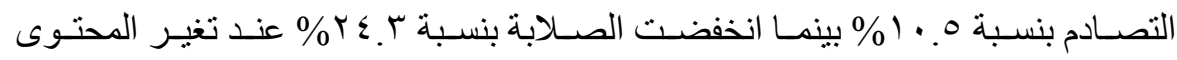

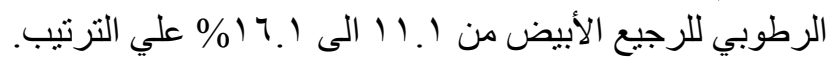

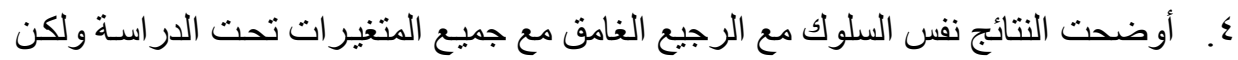

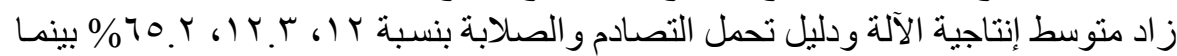

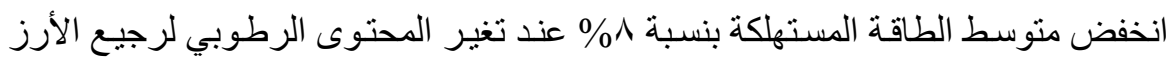

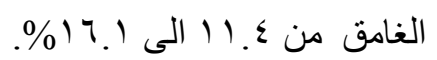
•. تم استتباط نماذج رياضية توصف التغير فى أداء الآلة وجودة المصبعات نتيجة التغير فى التى

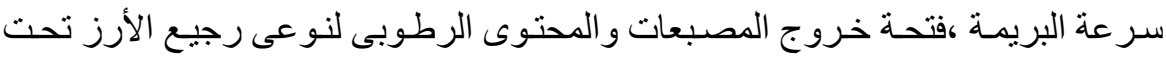

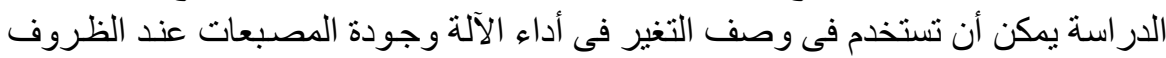

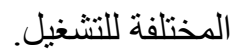
من هذه الدر اسـة يتضـح إمكانية تشكيل مصبعات رجيع الأرز بهذه الآلة المطورة بكفاءة

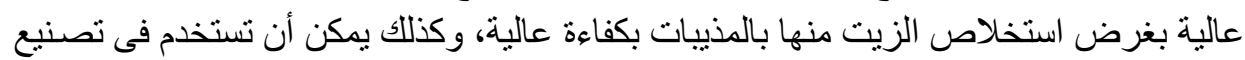

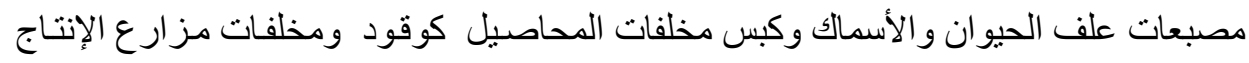
الحيو اني كسماد عضوي. 